\title{
Influence of Mineral and Organic Fertilizers on Rice Kernel Smut Disease Zeinab A. Kalboush ${ }^{1}$; A. M. Ghoneim ${ }^{2}$ and A. A. Hassan ${ }^{1}$ \\ ${ }^{1}$ Rice Pathology Department, Plant Pathology Research Insttitute, Agricultural Research Center, Egypt. \\ ${ }^{2}$ Rice Research and Traing Center, Field Crops Research Insttitute, Agricultural Research Center, Egypt.
}

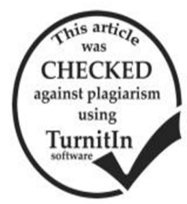

\section{ABSTRACT}

Disease resistance of rice plant is mainly genetically controlled but has a close association with the soil fertility status of the plants or pathogens; and thus, nutrient management has always been an important regulator for rice plant diseases. There is a dynamic interrelation between the soil fertility of rice plants with pathogen and abiotic environment, and hence, proper management of nutrients in cultivated rice crop can effectively reduce the severity of most diseases. Therefore, the current research is aimed to investigate the effects of mineral and organic fertizers of kernel smut incidence disease on the Giza 178 rice cultiver. Laboratory and field experiments were carried out at Rice Research \& Training Center (RRTC) during 2016 and 2017 grwoing seasons. Kernel smut disease, caused by Tilletia barclayana was isolated and identificated in this study. Pathogenicity test was carried out on Giza 171, the most sensitive rice cultivar. While Giza 178 was used to field evaluated. Randomized complete block design (RCBD) experiment with three replicates was used. Farm yard manure (FYM), compost and different $\mathrm{P}, \mathrm{K}$ and $\mathrm{Zn}$ combinations (total 15 treatments) with and without urea application were used. Chlorophyll content, leaf area, total protein, total carbohydrate, rice grain yield, disease assessment, plant analysis for total $\mathrm{N}$, $\mathrm{P}, \mathrm{K}$ and $\mathrm{Zn}$ were estimated. The results indicated that, the highest $\mathrm{N} \%$ content was obtained from $\mathrm{FYM}+\mathrm{Zn}$ and $\mathrm{P}+$ compost combination. There were significant differences between FYM, composts and mineral fertilizer application with and without urea on rice disease incidence. Also, chlorophyll content, leaf area and grain yield were significantally affected by applying mineral and organic fertilizer with and without urea application. The hulling $\%$ and milling $\%$ decreased by increasing the disease severity. The infection $\%$ of Giza 178 rice cultivar without urea application ranged from $6.5 \%$ to $10.20 \%$ in 2016 and 2017 seasons, respectively, while with application of urea increased the infection $\%$ to the range from $21.75 \%$ to $24.50 \%$ in the same seasons.

Keywords: Kernel smut incidence, rice yield, organic fertilizer, mineral fertilzer.

\section{INTRODUCTION}

Kernel smut is a fungal rice disease caused by $T$. barclayana. This disease is a serious threat affecting negatively on rice yield and grains quality. Rice yield losses caused by kernel smut range from $1 \%$ to $15 \%$ (Ladhalakshmi et al., 2012). Kernel smut appears as a black mass of chlamydospores that replace all or part of individual kernels near or at maturity (Alice et al., 2003). Usually, only a small number of kernels in each panicle are infected. Completely smutted kernels may be slightly swollen while others may break open exposing the dark spores (Mandhare et al., 2008). These black spores make the disease easy to recognizes. If the disease is severe, a dark cloud of spores may be observed coming from the harvesters. Rice kernel smut incidence is affected by rice cultivars (Slaton et al., 2007), seeding rate or their interaction. However, its has been proven that this disease is nor affected by air temperature nor by precipitation (Biswas, 2003) and Zemolin et al., (2009) reported the rice kernel smut ( $T$. barclayana), which is considered as a secondary disease, lately has been growing in importance due to its high infestation levels and effects in rice yield.

The most important for high yielding rice production is soil fertility management which may affect the response of rice plants to diseases due to the change of microclimate under rice plant canopy (Altieri and Nicolls, 2003). The knowledge of soil fertility is a basis for setting up a high yield production system. The capacity of a resistant plant to diseases is strictly related to optimal physical, chemical and mainly biological characteristics of soils. Nitrogen management studies suggest that high preflooding applications of nitrogen increases kernel smut severity but only when environmental conditions are favourable for disease incidence (Slaton et al., 2004). Application of organic materials alone or in combination with inorganic fertilizer help in maintenance of soil fertility and crop productivity (Assefa, 2015). The understanding of these interactions between different sources of mineral and organic fertilizers and disease becomes the basis for design of the sustainable rice production system. Therefore, the current research aimed to investigate the effects of mineral and organic fertilzers on incidence of kernel smut in Giza 178 rice cultivar.

\section{MATERIALS AND METHODS}

Isolation, Identification and pathogen culture preparation

Isolates of rice kernel smut fungus were undertaken according to Anil and Singh (1987). The fungus was identified morphologically and microscopically, and type of germination was recoanized at Rice Plant Pathology Lab. at RRTC using the key given by Fischer and Holton (1957). The source of isolaties were isolated from different rice cultivares and governorates as Table 4.The fungus was grown on Potato dextrose agar media, then incubated at $26 \pm 2^{\circ} \mathrm{C}$ for 7 days. Plates were exposed to continuous fluorescent light for 48 hours to enhance sporulation. Inoculum of secondry sporidia suspension was prepared with adding $10 \mathrm{ml}$ sterilized water in each dish. Mycelia mats were harvested by spatula and filtered through cheese cloth. Spore suspension was adjusted to $5 \times 10^{7}$ secondary sporidia per $\mathrm{ml}$.

\section{Scanning Electron Microscopy (SEM)}

The morphology of culture for T. barclayana was examined by SEM using Jeol Scanning (Electron Microscope model JSM- 5500lv at Electron Microscope Unit, Tanta University) to identifying the fungus.The spores pathogen were grown on potato dextrose agar for 7 days at $28^{\circ} \mathrm{C}$. Preparation of specimens for SEM was carried out according to Manzali et al. (1993). One $\mathrm{cm}^{2}$ was excluded for SEM. The mycelial sample region was fixed with osmium oxide and then dehydrated using a serial dilution of ethylalcohol, then finally acetone. The processed sample was then dried using a critical point drier (EMS 850) coated with gold using a sputter coater (EMS 
550), then the sample was examined using a SEM (Jeol 100cx-11 ASID-4D).

\section{Greenhouse Experiment and Pathogenicity test}

Fourty two isolates of $T$. barclayana isolated from different location and cultivars. Giza 171 rice cultivar (sensitive Egyptian cultivar for rice kernel smut disease) was used with three replication, and seeded in plastic pots $25 \mathrm{~cm}$ diameterX $30 \mathrm{~cm}$. the pots were kept in the greenhouse at $25 \pm 30^{\circ} \mathrm{C}$ and fertilized with urea $46.5 \% \mathrm{~N}$ $(5 \mathrm{gm} / \mathrm{plot})$. Plants at flowering stage were sprayed with $5 \times 10^{7}$ secondary sporidia $\mathrm{ml}^{-1}$ of each isolate using electrical spray gun (atomizer). The inoculated plants were held in a moist chamber with at least 95\% RH and $25 \pm 28^{\circ} \mathrm{C}$ for $24 \mathrm{hrs}$ and then kept in the greenhouse till maturity. Disease severity was assessed using number of infected grains and total number of grains per panicles (Slaton et al., 2004).

\section{chemical analysis} Soil and organic fertilizer samples

Soil samples were collected from RRTC experimental farm, Sakha, Kafr El-Sheikh, Egypt. Soil samples were air-dried at room temperature for two weeks and then sieved by 2-mm stainless steel sieve. The $\mathrm{pH}$ and EC of samples were measured (using 1: 2.5 ratio with distilled water) by $\mathrm{pH}$-meter and the EC meter, respectively. Particle size distribution was analyzed according to Gee and Bauder (1996). Organic matter was dtermined according to Allison (1965) while available P, K and $\mathrm{Zn}$ were measured using the methods of Watanabe and Olsen, (1956) and Jackson (1967), respectively. Some selected soil and organic fertilizer properties are shown in Tables 1 and 2.

Table 1. Some chemical and physical properties of soil used

\begin{tabular}{lccc}
\hline Property & $\mathbf{2 0 1 6}$ & $\mathbf{2 0 1 7}$ & Method \\
\hline EC $\left(\mathrm{dS} \mathrm{m}^{-1}\right)$ & 2.50 & 3.70 & EC-meter \\
pH $(1: 2.5)$ & 7.84 & 7.63 & pH-meter \\
Oranic matter $(\%)$ & 1.30 & 1.28 & Allison $(1965)$ \\
Total N $\left(\mathrm{mg} \mathrm{kg}^{-1}\right)$ & 22.4 & 39.2 & Bremner $(1965)$ \\
Available P $\left(\mathrm{mg} \mathrm{kg}^{-1}\right)$ & 7.50 & 9.57 & Watanabe and Olsen $(1965)$ \\
Available Zn $\left(\mathrm{mg} \mathrm{kg}^{-1}\right)$ & 2.00 & 2.35 & Jackson $(1967)$ \\
Available K $\left(\mathrm{mg} \mathrm{kg}^{-1}\right)$ & 138.6 & 168.0 & Jackson $(1967)$ \\
Sand \% & 21.40 & 21.8 & Gee and Bauder $(1996)$ \\
Silt \% & 29.0 & 28.4 & Gee and Bauder $(1996)$ \\
Clay \% & 49.6 & 49.8 & Gee and Bauder $(1996)$ \\
Texture & Clayey & Clayey & \\
\hline
\end{tabular}

Table 2. Chemical properties of farmyard manure and compost used in the experiment

\begin{tabular}{lccc}
\hline Property & Farmyard manure & Compost & Method \\
\hline Total $\mathrm{N} \%$ & 1.50 & 0.95 & Bremner (1965) \\
Total C\% & 29.5 & 18.0 & Allison (1965) \\
C:N ratio & 19.6 & 18.3 & \\
Total P $\left(\mathrm{mg} \mathrm{kg}^{-1}\right)$ & 0.21 & 0.15 & Watanabe and Olsen (1965) \\
Total Zn $\left(\mathrm{mg} \mathrm{kg}^{-1}\right)$ & 62.0 & 75.0 & Jackson (1967) \\
Total K $\left(\mathrm{mg} \mathrm{kg}^{-1}\right)$ & 1.50 & 1.10 & Jackson (1967) \\
Oranic matter $(\%)$ & 53.5 & 31.5 & Allison (1965) \\
\hline
\end{tabular}

\section{Field evaluation:}

Randomized complete block design (RCBD) experiment with three replicates was adopted for each treatment on susceptible Giza $178 \mathrm{cv}$ under natural infection of kernel smut incidence. Effect of different nitrogen sources and $\mathrm{P}, \mathrm{K}$ and $\mathrm{Zn}$ as treatment are shown in Table 3.

Table 3. Treatments combination

\begin{tabular}{lc}
\hline Treatment & \\
\hline PKZn & $\mathrm{P}$ \\
FYM + PKZn & FYM + P \\
Compost + P K Zn & Compost + P \\
Zn & $\mathrm{K}$ \\
FYM + Zn & FYM + K \\
Compost + Zn & Compost + K \\
FYM & Compost \\
Control & \\
\hline
\end{tabular}

*The same treamenst were repeated with $150 \mathrm{~kg}$ urea application

The plot size was $3 \times 3 \mathrm{~m}$. After preparing the soil, added the quantity of FYM $\left(5 \mathrm{~m}^{3} /\right.$ Fadden), Compost (5 $\mathrm{m}^{3} /$ Fadden), Phosphor (100 kg/ Fadden) and 1:2 quantity of potassium (100 kg/ Fadden) were added to the dry soil. Zinc (10 kg/ Fadden) were added after preparing the plots. Thirty days old seedlings were transplanted in rows with three plants /hill. The other half of Potassium was added in flowering stage. Samples of rice grains were taken at the late maturity and all yield compontes were taken recorded beginning from two weeks after fertilization.

\section{Chlorophyll content}

Total chlorophyll content of rice leaves was determined using chlorophyll meter (SPAD-502) as method of Kalboush (2007).

\section{Plant analysis}

Dry oven rice leaves samples $(0.20 \mathrm{~g})$ from each treatment at flowering stage were digested with $5 \mathrm{ml}$ of $\mathrm{H}_{2} \mathrm{SO}_{4}+1 \mathrm{ml} \mathrm{HClO}_{4}$ acid $70 \%$ for $4 \mathrm{hrs}$ using a hot block heater. After cooling, the digest was transferred to a 50-ml volumetric flask and then filtered. Total $\mathrm{N}$ content was determined by the modified micro-Kjeldahi methods as described by Bremner (1965). Phosphorus (P) was determined calorimetrically by ascorbic acid according to Olsen et al. (1954). Potassium (K) was determined by the 
flame photometer as described by Jackson (1967). Zinc $\mathrm{Zn}$ ) concentrations of these samples were determined according to Jackson (1967), using atomic absorption spectrophotometry model (2380).

After harvest, rice grain samples were taken from each treatment and examined at grain quality Laboratory of the RRTC to determine some grain quality characters, as percentages of hulling, milling, total proteins and total carbohydrates.

Hulling \% was calculated according to Adair (1952) as follows:

$$
\begin{array}{ll}
\text { Hulling }(\%)= & \text { Weight of brown rice }(\mathrm{g}) \\
\text { Milling }(\%)= & \begin{array}{l}
\text { Weight of rough rice }(\mathrm{g}) \\
\text { Weight of milled rice }(\mathrm{g})
\end{array} \\
\text { Weight of rough rice }(\mathrm{g}) & \times 100
\end{array}
$$

\section{Determination of total protein}

Total protein content was determined by the modified micro-kjeldahi method as described by Bremner (1965). Grain materials which were randomly collected from each plot were oven dried at $70^{\circ} \mathrm{C}$ for 3 days, then ground and samples were triplicated to indicate the levels of protein and carbohydrate. The milled grain sample $(0.20 \mathrm{~g})$ was digested as described above. Ten Ml from digested solution were added to $10 \mathrm{ml} \mathrm{NaOH} 20 \%$ solution and diluted up to $100 \mathrm{ml}$ by distilled water and left for 30 minutes in micro-Kjeldahi. The protein content in the grains $(\%)$ was calculated by multiplying $\mathrm{N}$ content of the grains $(\%)$ with the conversion factor of 6.25 as reported by Anon (1962).

\section{Determination of total carbohydrate}

Total Carbohydrates were determined in digestion suspension by adding $\left(5 \mathrm{ml}\right.$ phenol $\left.+5 \mathrm{ml} \mathrm{H}_{2} \mathrm{SO}_{4}\right)$. The absorbance was measured at $490 \mathrm{~nm}$ using spectrophotometer (Milton Roy, Spectronic, 1201 Digital) according to the method described by Herbert et al. (1971).

\section{Disease Assessment}

Disease severity of infection was estimated with calculated 400 randomly grain during harvested yield from each plot, the grains examind and calculating the number of smut grains to musered infection severity according to the (IRRI, 2002) as following:

Disease Severity $\%=\frac{\text { No. of infected grain/panicles }}{\text { Total no. of rice grain/ panicles }} \times 100$

Disease infection percentage was measured with collecting hundered panicles randomly from each plot and calculated as panicles condacted one or more smut grains, measured infection percentage according to formula (Slaton et al., 2004) as following:

\section{Disease Infection \% $=\frac{\text { No. of infected panicles }}{\text { Total no. of rice panicles }} \times 100$ \\ Statistical analysis \\ Data were statistically analyzed using standard} statistical analysis with MSTATC pakcage. In the table of main treatments, Ducan Multiple Range Test (Range, 1955) was applied to compare the significantly different averages by using critical difference values at 5\% level of probability

\section{RESULTS AND DISCUSSION}

\section{Isolation and Identification}

Kernel smut disease caused by $T$. barclayana appeared at leate maturity as in (Fig. 1A and B). Our results under steriomicrosope indicated that a black mass of ooze pushes out of the hull to become visible. By the time, the teliospore masses dry down to a powder and can easily be rubbed off on fingers. The isolates were identified according to their morphological characteristics as $T$. barclayana (Bref.) Sacc. and Syd. Morphological characters of the teliotospores are light brown to black, globose or sub-globose measuring $12-35 \mu \mathrm{m}$ in diameter with or without an appendage in (Fig. 1C). Along with these spores, sterile cells are also found in the powdery mass which are more or less globose, hyaline to yellowish tinted, 10-30 $\mu \mathrm{m}$ in diameter in (Fig.1C). Teliospore germinated producing promycelium in (Fig.1D1) which produces a large number of primary sporidia (basidiospores) in Fig (1D2\&3). The promycelium is mostly simple, non-septate to $1-3$ septate, $7 \mu \mathrm{m}$ in diameter and $35-52 \mu \mathrm{m}$ in length. The primary sporidia are long, cylindrical to filliform or needle shaped with flat base and pointed tip measuring $35-60 \mu \mathrm{m}$ in length, $1.3-2 \mu \mathrm{m}$ in size in Fig (1E1\&2). Each haploid cell of the basidiospore in fig $(1 \mathrm{~F})$ can produce hyphae, filiform sporidia after the mating gave the secondary sporidia in Fig (1G1), and it is the primary infective unit of such fungus. The seconddary sporidia are hyaline and curved/allantoid, 7.5-14 x 1.2-2 $\mu \mathrm{m}$ in size under electron microscope in Fig (1G2,3 and 4). Matsumoto et al. (1985) observed considerablle variation in teliospores of different isolates of $\mathrm{N}$. horrida in California. These morphological differences and range in variation were used to compile specific criterion for the identification of this species which can be used by quarantine personnels. This fungus was previously reported to be the causal agent of rice kernel smut disease (Takahashi, 1896; Biswas et al., 2003).

\section{Pathogenicity test}

Fourty two kernel smut isolate which collected from different cultivars and locations were carried out using Giza $171 \mathrm{cv}$ as the most susceptible one.The tested isolates varied in their virulence. Isolates number 12,28 , 29,11 and 14 previously isolated from diseased rice samples collected from Kafrelsheik, Dakahlia and Gharbia governorates, respectively proved to be the most aggressive isolates for Sakha 101 rice cv., Giza 178 and Giza 177. However, isolate no. 10 isolated from Kafrelsheikh governorate as was the least virulent one which gave the least disease severity among all tested isolates as indicated in Table (4). Pathogenecity tests revealed that these isolates were pathogenic to kernel rice with variable degrees (El-Kazzaz, et al., 2014). Sharma, et al. (2001) evaluated the pathogenisty test for $T$. barclayana using different forms of spores viz. primary as well as secondary sporidia by the syringe and spray methods in a field experiment. The plants were inoculated with secondary sporidia $8 \times 10^{5}$ sporidia/ml $(10 \mathrm{ml} /$ culture tube) at evening. The plants injected at late boot to early heading stage, exhibited $100 \%$ panicle infection. The highest grain infection ranged from 38.4 to $62.2 \%$ (average of $48.3 \%$ ) using the syringe method and from 8.5 to $12.7 \%$ (average of $10.9 \%$ ) using the spray method. 


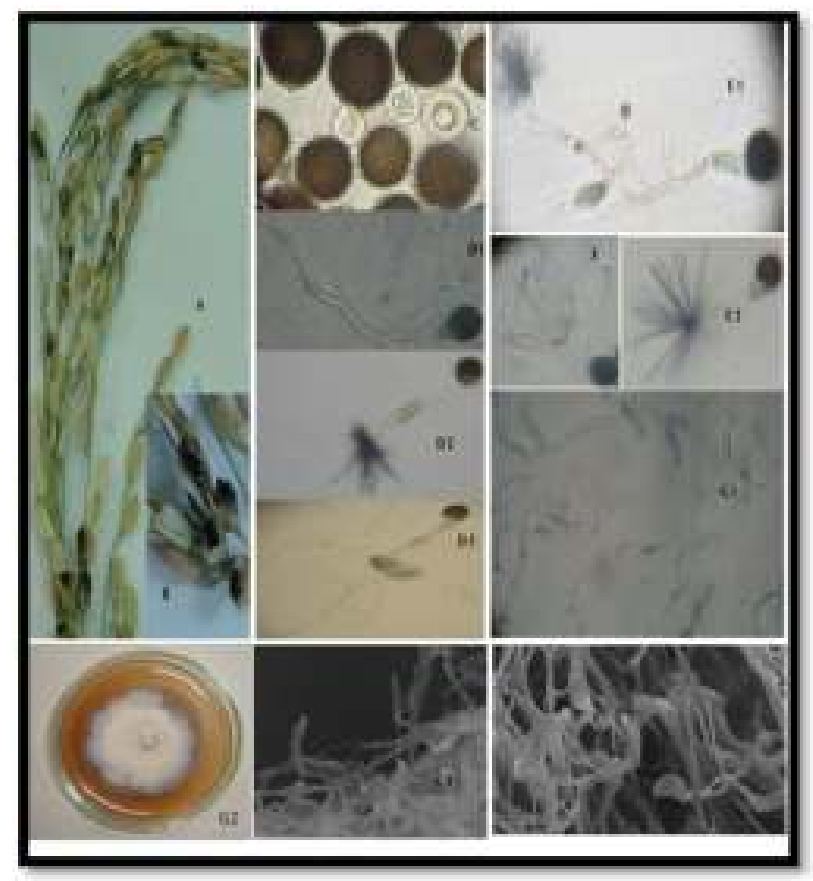

Fig. 1. Types of symptoms of rice kernel smut disease (A \& B), Teliospore (C) X 100, Teliospore gramination (D 1) X 100, promycelium and different shapes of teliospore germination (D2, D3, E1\&E2)X100, a large number of primary sporidia (F) $X$ 100, seconddary sporidia (G1) X 100, seconddary sporidia in PDA (G2), seconddary sporidia and secondary mycelium (G3) X 2.000, and (G4) X 3.500 of $T$. barclayana the causal agent of rice kernel smut disease.

Table 4. Pathogenicity test of isolates of $T$. barclayana isolated from rice cultivars grown at different governortes during 2016 growing season using Giza 171 cultivar under greenhouse condition

\begin{tabular}{|c|c|c|c|c|}
\hline No. & Location & Source of isolate & Disease severity(\%) & Disease incidence(\%) \\
\hline 1 & & Giza178 & $1.50 \mathrm{~m}-\mathrm{q}$ & $9.34 \mathrm{n}-\mathrm{r}$ \\
\hline 2 & & Giza178 & $2.00 \mathrm{i}-\mathrm{n}$ & $15.00 \mathrm{i}-1$ \\
\hline 3 & & Giza178 & $3.50 \mathrm{de}$ & $18.34 \mathrm{~g}-\mathrm{j}$ \\
\hline 4 & & Giza178 & $1.26 \mathrm{n}-\mathrm{s}$ & $11.00 \mathrm{l}-\mathrm{p}$ \\
\hline 5 & & Sakha 104 & $2.43 \mathrm{~g}-1$ & $24.00 \mathrm{ef}$ \\
\hline 6 & & Sakha 104 & $1.86 \mathrm{j}-\mathrm{o}$ & $25.00 \mathrm{ef}$ \\
\hline 7 & Kafrelsheikh & Hybrid 1 & $0.037 \mathrm{u}$ & $8.00 \mathrm{pqr}$ \\
\hline 8 & & Hybrid 1 & $0.45 \mathrm{stu}$ & $14.67 \mathrm{j}-\mathrm{m}$ \\
\hline 9 & & Sakha101 & $0.43 \mathrm{stu}$ & $16.34 \mathrm{ijk}$ \\
\hline 10 & & Sakha101 & $0.013 \mathrm{u}$ & $6.34 \mathrm{r}$ \\
\hline 11 & & Sakha101 & $4.50 \mathrm{bc}$ & $38.34 \mathrm{~b}$ \\
\hline 12 & & Sakha101 & $6.70 \mathrm{a}$ & $43.34 \mathrm{a}$ \\
\hline 13 & & Giza177 & 3.03 e-h & 26.34 de \\
\hline 14 & & Giza177 & $3.26 \mathrm{~d}-\mathrm{g}$ & $33.00 \mathrm{c}$ \\
\hline 15 & & Giza177 & $1.90 \mathrm{j}-\mathrm{O}$ & $17.00 \mathrm{~h}-\mathrm{k}$ \\
\hline 16 & Gharbia & Hybrid 1 & $2.63 \mathrm{f}-\mathrm{k}$ & $24.4 \mathrm{ef}$ \\
\hline 17 & & Hybrid 1 & $1.53 \mathrm{~m}-\mathrm{g}$ & $15.34 \mathrm{ijk}$ \\
\hline 18 & & Giza 178 & $2.30 \mathrm{~h}-\mathrm{m}$ & $25.00 \mathrm{ef}$ \\
\hline 19 & & Giza 178 & $1.53 \mathrm{~m}-\mathrm{q}$ & $21.67 \mathrm{fg}$ \\
\hline 20 & & Giza 178 & $0.31 \mathrm{k}-\mathrm{u}$ & $12.67 \mathrm{k}-\mathrm{o}$ \\
\hline 21 & & Giza 178 & $1.53 \mathrm{~m}-\mathrm{q}$ & $19.00 \mathrm{~g}-\mathrm{j}$ \\
\hline 22 & & Giza 178 & $1.06 \mathrm{o}-\mathrm{t}$ & $18.00 \mathrm{~g}-\mathrm{j}$ \\
\hline 23 & & Giza 178 & $1.53 \mathrm{~m}-\mathrm{q}$ & $13.34 \mathrm{k}-\mathrm{n}$ \\
\hline 24 & & Giza 178 & $0.02 \mathrm{u}^{\mathrm{T}}$ & 9.34 n-r \\
\hline 25 & & Giza 178 & $0.05 \mathrm{u}$ & $6.67 \mathrm{ar}$ \\
\hline 26 & & Giza 178 & $1.80 \mathrm{k}-\mathrm{p}$ & $15.00 \mathrm{i}-1$ \\
\hline 27 & & Giza 178 & $0.76 \mathrm{q}-\mathrm{u}$ & $17.00 \mathrm{~h}-\mathrm{k}$ \\
\hline 28 & Dakahlia & Giza 178 & $6.30 \mathrm{a}$ & $32.34 \mathrm{c}$ \\
\hline 29 & & Giza 178 & $4.97 \mathrm{~b}$ & $40.34 \mathrm{ab}$ \\
\hline 30 & & Giza 178 & $2.86 \mathrm{e}-\mathrm{i}$ & $24.67 \mathrm{ef}$ \\
\hline 31 & & Giza 177 & $4.86 \mathrm{~b}$ & $24.34 \mathrm{ef}$ \\
\hline 32 & & Giza 177 & 3.43 def & $26.67 \mathrm{de}$ \\
\hline 33 & & Sakha 102 & $2.43 \mathrm{~g}-1$ & $19.34 \mathrm{ghi}$ \\
\hline 34 & & Sakha 102 & $2.67 \mathrm{e}-\mathrm{k}$ & $14.67 \mathrm{j}-\mathrm{n}$ \\
\hline 35 & & Hybrid 2 & $0.97 \mathrm{p}-\mathrm{t}$ & $10.67 \mathrm{~m}-\mathrm{q}$ \\
\hline 36 & & Hybrid 2 & $0.6 \mathrm{r}-\mathrm{u}$ & $9.00 \mathrm{o}-\mathrm{r}$ \\
\hline 37 & & Giza 178 & $3.90 \mathrm{~cd}$ & $294 \mathrm{~cd}$ \\
\hline 38 & & Giza 178 & $1.47 \mathrm{~m}-\mathrm{r}$ & $15.67 \mathrm{ijk}$ \\
\hline 39 & & Hybrid 2 & $2.50 \mathrm{~g}-1$ & $24.00 \mathrm{kf}$ \\
\hline 40 & Damıetta & Hybrid 2 & $2.70 \mathrm{e}-\mathrm{j}$ & 19.34 ghi \\
\hline 41 & & Giza 177 & $1.701-\mathrm{p}$ & $15.00 \mathrm{i}-1$ \\
\hline 42 & & Giza 177 & $1.46 \mathrm{~m}-\mathrm{r}$ & $21.00 \mathrm{fgh}$ \\
\hline
\end{tabular}

Means followed by a common letter in a column are not significantly different at $5 \%$ level by DMRT. 
Effect of mineral and organic fertilizer on rice kernel smut disease severity and infection

Infection and severity of Giza $178 \mathrm{cv}$. as affected by application of chemical and organic fertilizers and their combinations are presented in (Tables 5 and 6). The results show that the mean infection and severity of rice cultivar without urea application ranged from 6.5 to $10.20 \%$ and from 0.05 to $0.20 \%$ in 2016 and 2017 growing seasons, respectively. Application of urea increased the rang from 21.75 to $24.50 \%$ and from 1.20 to $0.96 \%$, in 2016 and 2017 growing seasons, respectiveily. Balanced soil fertility leads to a healthy rice plant, which reduces the disease susceptibility and infection. Thus, it is important to provide a balanced nutrition at the time when the nutrient can be most effectively used for disease control. Not only fertilization can affect the disease development but also any management practice that affects the soil environment such as $\mathrm{pH}$ modification through liming or gypsum application, tillage, seedbed firmness, site of nursery, moisture control through irrigation (Ebid et al., 2007) and organic fertilizers (Al Harbi et al., 2013). Soils with high organic matter and active soil biological activity generally exhibit good soil fertility as well as complex food webs and beneficial organisms that minimize infection (Ramesh et al,. 2005). Organic amendments encompass a wide range of products, from crop residues and wastes and animal manures to solid wastes and various rural/urban composts. Till date, most of the research has often concluded that addition of organic amendments to fields has a beneficial effect on the disease suppression (Khan et al., 2016; Ghoneim et al., 2016).

Table 5. Effect of FYM, compost, $P, K$ and $\mathrm{Zn}$ without urea application on kernel smut disease incidence in Giza 178 rice cultivar during 2016 and 2017 seasons

\begin{tabular}{|c|c|c|c|c|c|c|c|}
\hline \multirow{18}{*}{ 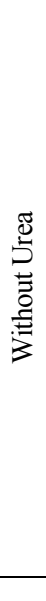 } & \multirow{2}{*}{ Treatment } & \multicolumn{2}{|c|}{ Infection (\%) } & \multirow{2}{*}{ Mean } & \multicolumn{2}{|c|}{ Severity (\%) } & \multirow{2}{*}{ Mean } \\
\hline & & 2016 & 2017 & & 2016 & 2017 & \\
\hline & PKZn & 7.500 & 5.500 & 6.500 & 0.075 & 0.023 & 0.050 \\
\hline & FYM + PKZn & 15.00 & 13.50 & 14.25 & 0.625 & 0.410 & 0.520 \\
\hline & Compost+ P K Zn & 27.50 & 15.83 & 21.67 & 0.842 & 0.433 & 0.640 \\
\hline & $\mathrm{Zn}$ & 15.00 & 13.45 & 14.23 & 0.500 & 0.233 & 0.370 \\
\hline & FYM + Zn & 17.50 & 11.00 & 14.25 & 0.250 & 0.300 & 0.270 \\
\hline & Compost $+\mathrm{Zn}$ & 17.50 & 15.83 & 16.67 & 0.750 & 0.317 & 0.530 \\
\hline & $\mathrm{P}$ & 10.00 & 11.00 & 10.50 & 0.400 & 0.350 & 0.370 \\
\hline & FYM + P & 27.50 & 21.00 & 24.50 & 0.900 & 0.950 & 0.930 \\
\hline & Compost $+\mathrm{P}$ & 20.00 & 29.17 & 24.58 & 1.000 & 1.167 & 1.080 \\
\hline & $\mathrm{K}$ & 5.500 & 5.300 & 5.400 & 0.120 & 0.100 & 0.110 \\
\hline & FYM + K & 12.50 & 12.83 & 12.67 & 0.200 & 0.283 & 0.240 \\
\hline & Compost $+\mathrm{K}$ & 1.830 & 1.000 & 1.420 & 0.150 & 0.100 & 0.130 \\
\hline & FYM & 18.00 & 9.330 & 13.67 & 0.433 & 0.210 & 0.320 \\
\hline & Compost & 22.33 & 19.67 & 20.83 & 0.750 & 0.550 & 0.650 \\
\hline & Control & 12.00 & 8.330 & 10.20 & 0.250 & 0.153 & 0.200 \\
\hline & LSD, $5 \%$ & 2.720 & 2.120 & - & 0.320 & 0.300 & - \\
\hline
\end{tabular}

Table 6. Effect of FYM, Compost, P, K and Zn with urea application on kernel smut disease incidence of Giza 178 rice cultivar during 2016 and 2017 seasons

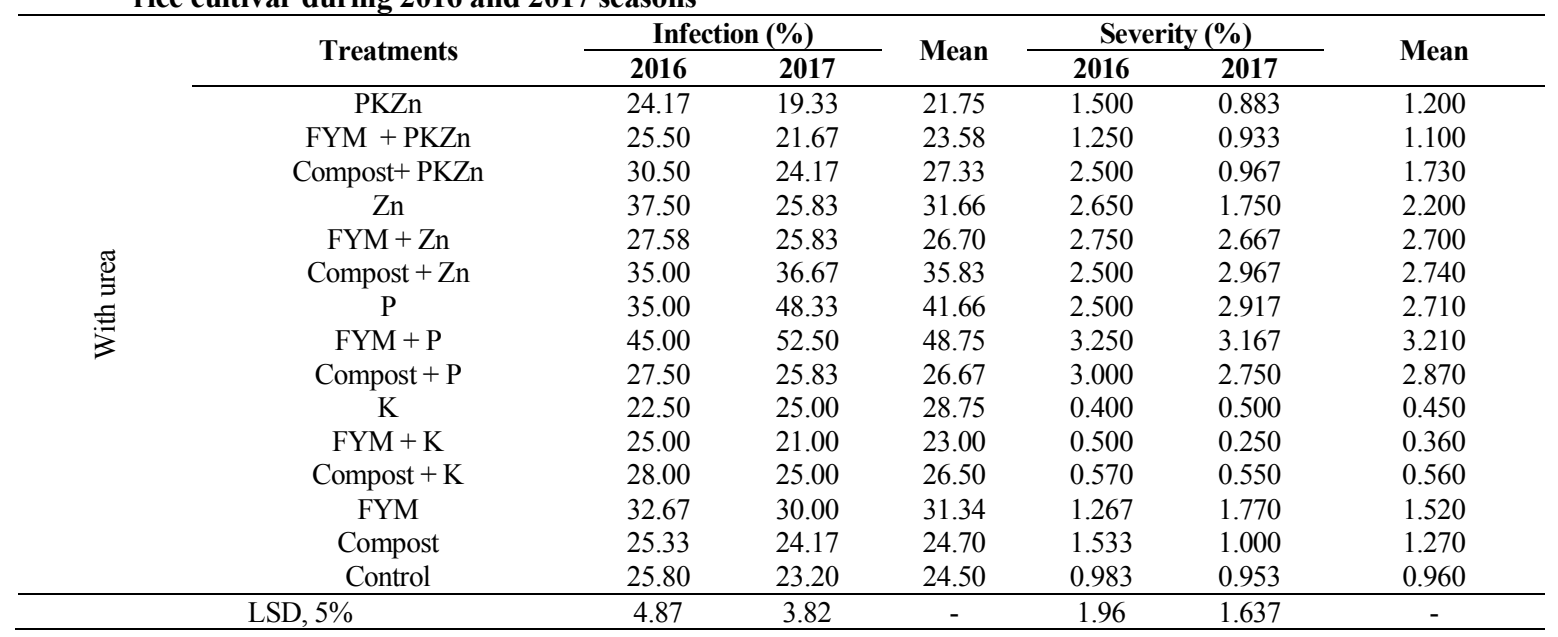

\section{Plant contents of $N, P, K$ and $Z n$}

The effects of mineral and organic fertilizer with and without urea application on concentration of $\mathrm{N}, \mathrm{P}, \mathrm{K}$, $\mathrm{Zn}$ and disease serverity of Giza 178 rice cultivar at flowering stage are resented in (Tables 7 and 8). The results show that the highest $\mathrm{N} \%$ content was obtained from FYM $+\mathrm{Zn}$ and $\mathrm{P}+$ compost. Nitrogen content in rice plants due to the different application of organic fertilizer was higher than those fertilized without any of the used elements except $\mathrm{Zn}$ in 2016 season proved increasing of $\mathrm{N}$ content. Generally, N\% was lower in 2017 season than in 2016 season. These results indicate that FYM+Zn and 
$\mathrm{P}+$ compost are responsible for the increased kernel smut disease severity (Tables 7 and 8). The increased $\mathrm{N}$ contents of rice plant tissues predisposed rice plants to infection with kernel smut disease. In concern to $\mathrm{P}, \mathrm{K}$ and $\mathrm{Zn}$ contents in rice plant tissue, results indicated that there were variation in $\mathrm{P}, \mathrm{K}$ and $\mathrm{Zn}$ contents of Giza 178 fertilized by recommended rates of $\mathrm{P}, \mathrm{K}$ and $\mathrm{Zn}$. Nitrogen content of rice plant increased in response to increasing other elements. Generally, all element contents in the tested rice plant were lower in 2016 season than in 2017 season. Data indicated that there were significant differences among sources of organic $\mathrm{N}$ fertilizers and application without urea of $\mathrm{P}, \mathrm{K}$ and $\mathrm{Zn}$ as reflected on rice disease incidence $\%$. The lowest kernel smut incidence $\%$ were recorded in plots received $\mathrm{K}, \mathrm{K}+\mathrm{FYM}$ and $\mathrm{K}+$ compost in both 2016 and 2017 growing seasons. Also, it was noticed that addition of FYM and compost to the soil increased the kernel smut incidence \%. The obtained results are in agreement with Atia (2004) they concluded that excessive nitrogen levels are rarely a problem of disease in organic production. On the other hand, P + FYM and $\mathrm{P}+$ compost induced the highest disease incidence in 2016 and 2017 grwing seasons. Macronutrients (N, P and $\mathrm{K})$ are equally important as with micronutrients such (Zn) in controlling the plant diseases. Micronutrients play a role in reducing the severity of different diseases due to the involvement in physiology and biochemistry of the plant because many of the important micronutrients are involved in many processes in plants which affects the response of plants to pathogens (Ghoneim et al. 2004). Micronutrients inhibit the pathogen from penetrating by affecting the cell wall rigidity and also the physical integrity of the membrane structure (Huber et al., 2012). The sources of organic matter for incorporation into the soil are becoming scarce. The FYM is the source of primary, secondary and micro nutrients for plant and is a constant source of energy for hetrotrophic micro organisms, which helps in increasing the availability of nutrients, quality and quantity of the crop produce (El-Refaee et al., 2014). In addition, micronutrients can also affect disease resistance indirectly, as nutrient-deficient plants not only exhibit an impaired defense mechanism but may also become more suitable for feeding as many metabolites such as sugars and amino acids leak out from cell (Huber et al. 2012). However, micronutrients are also known to reduce the severity by inducing the resistance within the plant that is called a systemic acquired resistance (Dordas, 2008).

Table 7. Effect of mineral and organic fertilizer on kernel smut disease using Giza 178 at flowering stage during 2016 and 2017 seasons

\begin{tabular}{lcccccccc}
\hline \multirow{2}{*}{$\begin{array}{l}\text { Treatment } \\
\text { (without Urea) }\end{array}$} & \multicolumn{2}{c}{ N content(\%) } & \multicolumn{2}{c}{ P Content(\%) } & \multicolumn{2}{c}{ K Content(\%) } & \multicolumn{2}{c}{ Zn Content(ppm) } \\
\cline { 2 - 8 } PKZn & $\mathbf{2 0 1 6}$ & $\mathbf{2 0 1 7}$ & $\mathbf{2 0 1 6}$ & $\mathbf{2 0 1 7}$ & $\mathbf{2 0 1 6}$ & $\mathbf{2 0 1 7}$ & $\mathbf{2 0 1 6}$ & $\mathbf{2 0 1 7}$ \\
FYM + PKZn & 0.700 & 0.756 & 0.080 & 0.015 & 1.407 & 1.085 & 20.33 & 16.95 \\
Compost+ P K Zn & 1.120 & 0.867 & 0.092 & 0.028 & 1.513 & 1.245 & 28.10 & 23.68 \\
Zn & 0.980 & 0.588 & 0.086 & 0.054 & 1.193 & 1.340 & 25.97 & 24.53 \\
FYM + Zn & 1.260 & 0.672 & 0.091 & 0.029 & 1.341 & 1.283 & 25.67 & 23.53 \\
Compost + Zn & 1.800 & 0.700 & 0.118 & 0.036 & 1.532 & 1.183 & 30.02 & 23.20 \\
P & 1.120 & 0.812 & 0.099 & 0.040 & 1.438 & 1.198 & 23.94 & 21.87 \\
FYM + P & 0.980 & 0.743 & 0.079 & 0.048 & 1.404 & 1.210 & 16.68 & 17.18 \\
Compost + P & 1.330 & 0.812 & 0.100 & 0.067 & 1.550 & 1.167 & 16.70 & 17.16 \\
K & 2.107 & 1.560 & 0.118 & 0.060 & 1.406 & 1.140 & 17.23 & 23.93 \\
FYM + K & 0.980 & 0.588 & 0.055 & 0.034 & 1.266 & 1.1270 & 17.20 & 15.33 \\
Compost + K & 1.260 & 0.728 & 0.064 & 0.030 & 1.681 & 1.435 & 17.78 & 18.55 \\
FYM & 0.770 & 0.746 & 0.090 & 0.024 & 1.740 & 1.667 & 18.25 & 21.33 \\
Compost & 1.610 & 0.976 & 0.131 & 0.028 & 1.513 & 1.225 & 21.05 & 17.00 \\
Control & 0.980 & 0.812 & 0.382 & 0.030 & 1.373 & 1.140 & 17.12 & 19.15 \\
LSD, 5\% & 0.640 & 0.539 & 0.85 & 0.025 & 1.770 & 1.003 & 15.00 & 15.36 \\
\hline
\end{tabular}

Table 8. Effect of mineral and organic fertilizer with applied on kernel smut disease using Giza 178 at flowering stage during 2016 and 2017 seasons

\begin{tabular}{lcccccccc}
\hline \multirow{2}{*}{$\begin{array}{l}\text { Treatment } \\
\text { with Urea }\end{array}$} & \multicolumn{2}{c}{ N content(\%) } & \multicolumn{2}{c}{ P Content(\%) } & \multicolumn{2}{c}{ K Content(\%) } & \multicolumn{2}{c}{ Zn Content(ppm) } \\
\cline { 2 - 8 } PKZn & $\mathbf{2 0 1 6}$ & $\mathbf{2 0 1 7}$ & $\mathbf{2 0 1 6}$ & $\mathbf{2 0 1 7}$ & $\mathbf{2 0 1 6}$ & $\mathbf{2 0 1 7}$ & $\mathbf{2 0 1 6}$ & $\mathbf{2 0 1 7}$ \\
FYM + PKZn & 1.240 & 0.925 & 0.100 & 0.051 & 1.853 & 1.560 & 17.80 & 24.10 \\
Compost+ P K Zn & 1.680 & 1.00 & 0.120 & 0.022 & 1.856 & 1.530 & 28.45 & 28.98 \\
Zn & 1.680 & 0.975 & 0.108 & 0.038 & 1.796 & 1.557 & 18.25 & 26.70 \\
FYM + Zn & 1.540 & 0.920 & 0.079 & 0.028 & 1.720 & 1.215 & 23.65 & 27.90 \\
Compost + Zn & 1.440 & 1.260 & 0.120 & 0.013 & 1.866 & 1.182 & 26.60 & 26.58 \\
P & 1.400 & 0.812 & 0.100 & 0.016 & 1.870 & 1.188 & 25.52 & 25.60 \\
FYM + P & 1.690 & 1.925 & 0.380 & 0.059 & 1.870 & 1.192 & 19.40 & 20.70 \\
Compost + P & 1.940 & 1.900 & 0.126 & 0.037 & 1.890 & 1.170 & 21.4 & 18.67 \\
K & 2.090 & 2.585 & 0.124 & 0.032 & 1.846 & 1.187 & 20.33 & 18.48 \\
FYM + K & 1.610 & 0.925 & 0.094 & 0.029 & 1.803 & 1.470 & 16.51 & 21.50 \\
Compost + K & 0.925 & 0.812 & 0.054 & 0.020 & 1.833 & 1.760 & 17.30 & 17.72 \\
FYM & 0.917 & 0.812 & 0.098 & 0.023 & 1.811 & 1.795 & 16.3 & 21.50 \\
Compost & 1.277 & 1.120 & 0.132 & 0.028 & 1.956 & 1.497 & 15.70 & 22.95 \\
Control & 1.357 & 1.075 & 0.108 & 0.030 & 1.855 & 1.240 & 17.97 & 21.33 \\
LSD, 5\% & 2.107 & 0.925 & 0.080 & 0.25 & 1.770 & 1.195 & 16.62 & 17.80 \\
\hline
\end{tabular}


Growth parameters, rice yield and grain quality

Growth parameters including chlorophyll content (SPAD values), leaf area, plant height and grain yield are presnetd in tables 9 and 10. Chlorophyll content, leaf area, plant height and grain yield were significantally affected by applying mineral and organic fertilizer with and without urea application in both growing seasons. However, the urea applications increased chlorophyll content, leaf area, plant height and grain yield. Without urea application, the grain yield ranged from 2.65 to $3.24 \mathrm{t}$ /feddan. All mineral and organic fertilizer increased the grain yield compared to the control treatment. However, with urea application, the grain yield increased significantally and the grain yield varied from 3.25 to $3.68 \mathrm{t} /$ feddan. Organic fertilizer had significant influences on chlorophyll content, leaf area, plant height and grain yield. Micronutrient tissue concentration were not significantly correlated to panicle blast severities except for $\mathrm{Zn}$. The low panicle blast severities of improved cultivar Guarani were associated with high $\mathrm{K}$ and $\mathrm{Zn}$ and low $\mathrm{N}, \mathrm{P}$, and $\mathrm{Mg}$ tissue concentrations (Persson et al., 2003). Adequate nitrogen fertilization is a prerequisite to produce high rice yield and improve the grain quality, while $\mathrm{P}$ plays a key role in the energy related activities and development of the root system (Huber et al., 2012).

Table 9. Effect of FYM, compost, $P, K$ and $\mathrm{Zn}$ without $\mathrm{N}$ application on rice yield and some related characteristics during 2016 and 2017 seasons

\begin{tabular}{|c|c|c|c|c|c|c|c|c|c|}
\hline \multirow{18}{*}{ 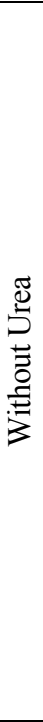 } & \multirow[t]{2}{*}{ Treatments } & \multicolumn{2}{|c|}{$\begin{array}{c}\text { Chlorophyll content } \\
\text { (SPAD) }\end{array}$} & \multicolumn{2}{|c|}{$\begin{array}{c}\begin{array}{c}\text { Leaf Area } \\
\left(\mathrm{cm}^{2}\right)\end{array} \\
\end{array}$} & \multicolumn{2}{|c|}{$\begin{array}{c}\begin{array}{c}\text { Plant height } \\
\text { (cm) }\end{array} \\
\end{array}$} & \multicolumn{2}{|c|}{$\begin{array}{r}\text { Grain yield } \\
\text { (t/ Feddan) }\end{array}$} \\
\hline & & 2016 & 2017 & 2016 & 2017 & 2016 & 2017 & 2016 & 2017 \\
\hline & PKZn & 33.0 & 34.7 & 15.0 & 16.5 & 76.4 & 81.7 & 2.66 & 2.65 \\
\hline & FYM + PKZn & 33.0 & 34.7 & 15.3 & 16.9 & 76.0 & 82.3 & 3.74 & 3.33 \\
\hline & Compost + PK Zn & 31.3 & 32.6 & 16.7 & 18.2 & 76.0 & 81.8 & 2.93 & 2.89 \\
\hline & $\mathrm{Zn}$ & 30.3 & 31.9 & 15.0 & 16.5 & 74.3 & 76.5 & 2.80 & 2.77 \\
\hline & $\mathrm{FYM}+\mathrm{Zn}$ & 31.3 & 32.9 & 14.0 & 15.4 & 71.6 & 80.5 & 2.98 & 2.95 \\
\hline & Compost $+\mathrm{Zn}$ & 31.3 & 32.7 & 15.3 & 17.1 & 73.6 & 79.1 & 2.99 & 2.83 \\
\hline & $\mathrm{P}$ & 32.3 & 33.7 & 15.0 & 16.6 & 73.7 & 76.0 & 2.93 & 2.89 \\
\hline & FYM + P & 33.0 & 34.5 & 14.3 & 15.7 & 75.7 & 77.9 & 3.08 & 3.03 \\
\hline & Compost $+\mathrm{P}$ & 30.0 & 31.4 & 14.0 & 15.3 & 73.7 & 76.1 & 2.98 & 2.95 \\
\hline & $\mathrm{K}$ & 33.0 & 34.5 & 12.3 & 13.8 & 72.3 & 74.5 & 2.94 & 2.92 \\
\hline & FYM + K & 33.0 & 34.5 & 16.6 & 17.9 & 80.3 & 85.5 & 3.56 & 3.42 \\
\hline & Compost $+\mathrm{K}$ & 32.0 & 33.7 & 10.7 & 12.1 & 71.6 & 74.0 & 3.28 & 3.24 \\
\hline & FYM & 34.0 & 35.5 & 15.7 & 17.3 & 82.3 & 84.6 & 3.02 & 3.04 \\
\hline & Compost & 32.3 & 33.5 & 16.7 & 18.4 & 79.0 & 81.2 & 3.04 & 3.08 \\
\hline & Control & 32.0 & 33.5 & 13.7 & 15.3 & 76.7 & 78.9 & 2.59 & 2.64 \\
\hline & LSD, $5 \%$ & 0.72 & 0.70 & 1.51 & 1.55 & 1.66 & 1.20 & 0.17 & 0.09 \\
\hline
\end{tabular}

Table 10. Effect of FYM, Compost, $P, K$ and $\mathrm{Zn}$ witht $\mathrm{N}$ application on rice yield and some related characteristics during 2016 and 2017 seasons..

\begin{tabular}{|c|c|c|c|c|c|c|c|c|c|}
\hline & \multirow[t]{2}{*}{ Treatments } & \multicolumn{2}{|c|}{$\begin{array}{c}\text { Chlorophyll content } \\
\text { (SPAD) }\end{array}$} & \multicolumn{2}{|c|}{$\begin{array}{l}\text { Leaf Area } \\
\left(\mathrm{cm}^{2}\right)\end{array}$} & \multicolumn{2}{|c|}{$\begin{array}{l}\text { Plant height } \\
\text { (cm) }\end{array}$} & \multicolumn{2}{|c|}{$\begin{array}{l}\text { Grain yield } \\
\text { (t/ Feddan) }\end{array}$} \\
\hline \multirow{17}{*}{ 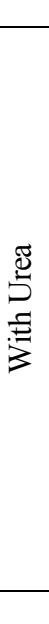 } & & 2016 & 2017 & 2016 & 2017 & 2016 & 2017 & 2016 & 2017 \\
\hline & PKZn & 40.6 & 42.3 & 35.0 & 37.9 & 93.0 & 95.5 & 3.53 & 3.56 \\
\hline & FYM + PKZn & 42.0 & 43.5 & 39.3 & 42.4 & 87.3 & 89.5 & 3.47 & 3.28 \\
\hline & Compost+PK Zn & 39.7 & 41.2 & 34.0 & 37.1 & 96.3 & 98.5 & 3.27 & 3.61 \\
\hline & $\mathrm{Zn}$ & 38.0 & 39.5 & 35.7 & 38.1 & 91.6 & 94.0 & 3.28 & 3.54 \\
\hline & $\mathrm{FYM}+\mathrm{Zn}$ & 41.7 & 43.6 & 32.7 & 34.7 & 91.6 & 93.8 & 3.44 & 3.52 \\
\hline & Compost $+\mathrm{Zn}$ & 39.0 & 40.2 & 39.7 & 41.9 & 94.7 & 96.7 & 3.17 & 3.39 \\
\hline & $\mathrm{P}$ & 39.0 & 40.6 & 35.3 & 36.7 & 93.3 & 95.6 & 3.05 & 3.43 \\
\hline & FYM + P & 41.3 & 42.2 & 32.3 & 33.7 & 85.7 & 87.8 & 3.16 & 3.61 \\
\hline & Compost $+\mathrm{P}$ & 39.0 & 40.5 & 35.0 & 39.8 & 97.3 & 99.3 & 3.24 & 3.48 \\
\hline & $\mathrm{K}$ & 40.3 & 42.0 & 42.7 & 45.0 & 92.0 & 94.2 & 3.93 & 3.68 \\
\hline & FYM + K & 42.3 & 43.9 & 31.0 & 33.4 & 83.7 & 85.7 & 3.87 & 3.28 \\
\hline & Compost $+\mathrm{K}$ & 38.0 & 39.3 & 37.0 & 38.5 & 93.7 & 95.7 & 3.52 & 3.57 \\
\hline & FYM & 42.0 & 43.3 & 39.0 & 41.4 & 91.3 & 93.5 & 3.81 & 3.33 \\
\hline & Compost & 42.3 & 43.4 & 33.3 & 34.8 & 94.7 & 96.8 & 3.81 & 3.69 \\
\hline & Control & 41.3 & 42.8 & 34.6 & 35.9 & 88.0 & 90.2 & 3.35 & 3.25 \\
\hline & LSD, $5 \%$ & 3.20 & 3.13 & 8.22 & 8.53 & 4.46 & 4.68 & 0.705 & 0.815 \\
\hline
\end{tabular}


Table 11. Effect of mineral and different sources of organic fertilizer without $\mathrm{N}$ application on some grain quality of Giza 178 rice cultivar during 2016 and 2017 seasons

\begin{tabular}{cccccc}
\hline & Treatment & \multicolumn{2}{c}{ Hulling(\%) } & \multicolumn{2}{c}{ Milling(\%) } \\
\cline { 2 - 5 } & $\mathbf{2 0 1 6}$ & $\mathbf{2 0 1 7}$ & $\mathbf{2 0 1 6}$ & $\mathbf{2 0 1 7}$ \\
\hline PKZn & 78.47 & 81.90 & 66.00 & 70.47 \\
& FYM + PKZn & 76.67 & 80.20 & 66.00 & 69.20 \\
Compost+ P K Zn & 79.33 & 82.73 & 65.33 & 69.60 \\
Zn & 79.00 & 82.10 & 65.33 & 68.77 \\
& FYM + Zn & 77.00 & 80.50 & 65.67 & 69.20 \\
Compost + Zn & 76.67 & 80.50 & 65.67 & 68.80 \\
P & 78.00 & 81.27 & 66.67 & 70.37 \\
FYM + P & 75.67 & 79.40 & 63.67 & 67.17 \\
& Compost + P & 79.00 & 82.47 & 66.67 & 70.09 \\
K & 79.67 & 83.27 & 68.67 & 71.77 \\
& FYM + K & 80.00 & 83.80 & 65.33 & 68.63 \\
& Compost + K & 77.67 & 80.58 & 66.00 & 69.30 \\
& FYM & 76.67 & 79.80 & 66.33 & 69.50 \\
& Compost & 78.67 & 82.03 & 67.33 & 70.67 \\
Control & 77.67 & 80.89 & 65.00 & 68.37 \\
\hline
\end{tabular}

Table. 12. Effect of mineral and different sources of organic fertilizer with $\mathbf{N}$ application on some grain quality of Giza rice cultivar during 2016 and 2017 seasons

\begin{tabular}{|c|c|c|c|c|c|}
\hline & \multirow{2}{*}{ Treatment } & \multicolumn{2}{|c|}{ Hulling(\%) } & \multicolumn{2}{|c|}{ Milling(\%) } \\
\hline & & 2016 & 2017 & 2016 & 2017 \\
\hline \multirow{16}{*}{ 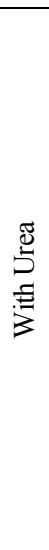 } & PKZn & 79.00 & 82.50 & 66.33 & 69.70 \\
\hline & FYM + PKZn & 78.00 & 81.03 & 63.00 & 66.43 \\
\hline & Compost+ P K Zn & 78.33 & 82.03 & 63.00 & 66.63 \\
\hline & $\mathrm{Zn}$ & 79.00 & 82.07 & 66.67 & 69.90 \\
\hline & FYM + Zn & 78.33 & 81.77 & 64.67 & 67.90 \\
\hline & Compost $+\mathrm{Zn}$ & 75.67 & 79.07 & 62.00 & 65.40 \\
\hline & $\mathrm{P}$ & 79.00 & 82.17 & 65.00 & 68.27 \\
\hline & FYM + P & 79.33 & 82.63 & 66.67 & 70.20 \\
\hline & Compost $+\mathrm{P}$ & 79.67 & 83.00 & 64.67 & 68.30 \\
\hline & $\mathrm{K}$ & 84.33 & 87.47 & 70.67 & 73.93 \\
\hline & FYM + K & 81.00 & 84.13 & 67.67 & 70.90 \\
\hline & Compost $+\mathrm{K}$ & 78.67 & 81.90 & 65.33 & 68.93 \\
\hline & FYM & 80.33 & 83.60 & 65.67 & 68.90 \\
\hline & Compost & 84.00 & 87.53 & 65.67 & 69.10 \\
\hline & Control & 77.33 & 80.67 & 64.67 & 68.00 \\
\hline & LSD, $5 \%$ & 1.994 & 1.951 & 4.044 & 4.080 \\
\hline
\end{tabular}

The rice grain quality i.e. hulling and milling $\%$ as affected by different rates of mineral and organic fertilzers are presented in Tables (11 and 12). In gernral, the results indicated that hulling and milling\% decreased by increasing the disease severity. On the other hand, total protein and total carbohydrate increased with the application of organic $\mathrm{N}$ fertilizers compared to control (Tables 13 and 14). Mineral nutrition has an important role in this system, and its management can affect not only the yield but also plant health and the environment (Katan, 2009). Total protein and total carbohydrate decreased by increasing the kernel smut disease severity in some cultivars and lines comparded with control because this disease replace the content of carbohydrate in rice grains with the fungus mass of teliospores (El-Kazzaz, et al., 2014).

Table 13. Total protein and total carbohydrate in rice plants as affected by mineral and organic fertilizer without applied urea during 2016 and 2017 seasons

\begin{tabular}{|c|c|c|c|c|c|}
\hline \multirow{18}{*}{ 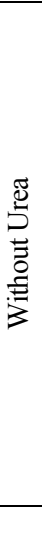 } & \multirow{2}{*}{ Treatment } & \multicolumn{2}{|c|}{ Total protein (\%) } & \multicolumn{2}{|c|}{ Total carbohydrate $(\mathrm{mg} / \mathrm{g})$} \\
\hline & & 2016 & 2017 & 2016 & 2017 \\
\hline & PKZn & 5.80 & 6.00 & 133.70 & 139.7 \\
\hline & FYM + PKZn & 7.46 & 7.66 & 120.00 & 126.0 \\
\hline & Compost+ P K Zn & 6.80 & 6.90 & 102.00 & 108.0 \\
\hline & $\mathrm{Zn}$ & 6.97 & 6.17 & 116.50 & 122.8 \\
\hline & $\mathrm{FYM}+\mathrm{Zn}$ & 7.46 & 7.66 & 117.25 & 113.3 \\
\hline & Compost $+\mathrm{Zn}$ & 6.75 & 6.95 & 120.00 & 136.0 \\
\hline & $\mathrm{P}$ & 6.93 & 6.13 & 121.20 & 127.2 \\
\hline & $\mathrm{FYM}+\mathrm{P}$ & 6.12 & 6.35 & 139.75 & 135.8 \\
\hline & Compost $+\mathrm{P}$ & 5.70 & 5.90 & 135.25 & 131.3 \\
\hline & $\mathrm{K}$ & 6.88 & 7.08 & 137.00 & 136.0 \\
\hline & FYM + K & 7.60 & 7.83 & 139.17 & 135.2 \\
\hline & Compost $+\mathrm{K}$ & 7.33 & 7.53 & 140.00 & 136.0 \\
\hline & FYM & 7.33 & 7.53 & 131.75 & 137.8 \\
\hline & Compost & 6.99 & 6.89 & 130.00 & 136.0 \\
\hline & Control & 7.50 & 7.70 & 138.50 & 136.5 \\
\hline & $\mathrm{D}, 5 \%$ & 1.42 & 1.40 & 11.57 & 6.21 \\
\hline
\end{tabular}


Table 14. Total protein and total carbohydrate in rice plants as affected by mineral and organic fertilizer with applied urea during 2016 and 2017 seasons

\begin{tabular}{|c|c|c|c|c|c|}
\hline & \multirow{2}{*}{ Treatment } & \multicolumn{2}{|c|}{ Total protein (\%) } & \multicolumn{2}{|c|}{ Total carbohydrate (mg/g) } \\
\hline & & 2016 & 2017 & 2016 & 2017 \\
\hline \multirow{16}{*}{ 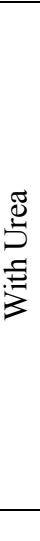 } & PKZn & 7.12 & 7.75 & 126.50 & 132.5 \\
\hline & FYM + PKZn & 6.80 & 7.00 & 133.33 & 139.3 \\
\hline & Compost+ P K Zn & 7.46 & 7.66 & 133.50 & 136.2 \\
\hline & $\mathrm{Zn}$ & 7.29 & 7.50 & 113.50 & 119.5 \\
\hline & $\mathrm{FYM}+\mathrm{Zn}$ & 7.40 & 7.93 & 114.75 & 120.8 \\
\hline & Compost $+\mathrm{Zn}$ & 7.05 & 7.45 & 113.00 & 119.0 \\
\hline & $\mathrm{P}$ & 7.16 & 7.56 & 115.50 & 114.7 \\
\hline & $\mathrm{FYM}+\mathrm{P}$ & 7.40 & 7.61 & 125.50 & 131.3 \\
\hline & Compost $+\mathrm{P}$ & 6.33 & 6.53 & 134.00 & 130.0 \\
\hline & $\mathrm{K}$ & 7.55 & 7.75 & 138.67 & 136.4 \\
\hline & $\mathrm{FYM}+\mathrm{K}$ & 7.28 & 7.58 & 139.25 & 135.0 \\
\hline & Compost $+\mathrm{K}$ & 7.12 & 7.22 & 126.42 & 132.0 \\
\hline & FYM & 7.33 & 7.53 & 131.00 & 137.0 \\
\hline & Compost & 7.33 & 7.53 & 135.00 & 134.3 \\
\hline & Control & 7.33 & 7.53 & 131.75 & 137.0 \\
\hline & LSD, 5\% & 0.67 & 0.85 & 5.200 & 4.880 \\
\hline
\end{tabular}

\section{REEFRENCES}

Adair, C.R. (1952). The McGill miller method for determining the milled quality of small samples of rice. Bangladesh Rice J. 55(2):21-23.

Al Harbi, S.F., A. M. Ghoneim, A. S. Modaihsh and M. O. Mahjoub, (2013). Effect of Foliar and soil application of phosphorus on phosphorus uptake, use efficiency and wheat grain yield in calcareous soil. Journal of Applied Sciences, 13(1): 188-192.

Alice, J, R.P Sujeetha and M.S. Venugopal (2003). Effect of organic farming on management of rice brown planthopper. IRRN 28.2: 36-37.

Allison, L.E., (1965). Organic Carbon. In: Methods of Soil Analysis, Black, C.A. (Ed.). American Society of Agronomy, USA., pp: 1367-1378.

Altieri, M.A. and C.I.Nicolls (2003). Soil fertility management and insect pests: harmonizing soil and plant health in agroecosystems. Soil \&Tillage Research, 72:203-211.

Anil, K. and R.A. Singh (1987). Effect of some physical and chemical factors on teliospore germination of Neovossia horrida. Indian-Phytopathology. 1987; 40(3): 337-341.

Anon (1962). pH values of food products. Food Eng., 34(3): 98-99.

Assefa, W.C. (2015). Response of barley (Hordium vulgare L.) to integrated cattle manure and mineral fertilizer application in the vertisol areas of south tigray, Ethiopia. J plant Sci3: 71-76.

Atia, M.M. (2004). Rice false smut (Ustilaginoidea virens) in Egypt. Journal of Plant Diseases and Protection 111: 71-82.

Biswas, A. (2003). Kernel smut disease of rice: current status and future challenges. Environ. Ecol. 21:336-51.

Biswas, A. Bastawaros, and A. Chandra (2003). atomistic mechanisms underlying chemical mechanical planarization of copper, Proceedings 2003 MRS Spring Meeting 767, F1.8

Bremner, J. M. (1965). Inorganic forms of nitrogen. In:C.A. Black(ed) Method of Soil Analysis, Part 2, Agronomy, 9:1179-1237.
Dordas, C. (2008). Role of nutrients in controlling plant diseases in sustainable agriculture: a review. Agron Sustain Dev., 28:33-46.

Ebid, A., H. Ueno and A.Ghoneim (2007). Impact of rice residues application on rice growth, yield and some paddy soil properties. International Journal of Agricultural Research, 2 (12): 1030-1036.

El-kazzaz, M. K.; G. A. E. Nasr El-kot; K. E. Ghoneim; M. M. Elsharkawy; Zeinab A.E. Kalboush and M. Hyakumachi (2014). Incidence of kernel smut caused by Tilletia barclayna in Egyptian rice cultivars. African Journal of Microbiology Research, 8 (32): 3052-3063.

EL-Refaee, I.S.; A.M. Ghoneim; and W.H. El-Kallawy (2014). Rice grain yield and water productivity as influenced by $\mathrm{N}$-fertilizer and compost under flooded and non-flooded conditions. Egypt J. Agric. Res., 93, 2B: 567-583.

Fischer, G.W. and C.S. Holton (1957) Biology and control of the smut fungi. Ronald Press, New York. Mycologia, 60: 655-662.

Gee, G.W.and J.W.Bauder (1996). Particle Size Analysis, ${ }^{3}$ rd Ed. In: Methods of Soil Analysis. Part 1: Physical and Mineralogical Methods, S.S.S.A. and American Society of Agronomy, Madison, WI, pp. 377-382.

Ghoneim, A., H. Ueno A.Ebid (2004). Nutrients dynamics in Komatsuna growing soil fertilized with biogas slurry by ${ }^{15} \mathrm{~N}$ dilution method. Abstracts of the annual meeting, Japanese Society of Soil Science and Plant Nutrition, 51, p. 293.

Ghoneim, A.M. (2016). Effect of different methods of $\mathrm{Zn}$ application on rice growth, yield and nutrients dynamics in plant and soil. Journal of Agriculture and Ecology Research International, 6(2):1-9.

Herbert, D., P.Phipps, R.E.Stranage (1971). Chemical analysis of microbial cells. Methods Microioal., 5B, 209-344.

Huber, D.M, Römheld V, Weinmann M. (2012). Relationship between nutrition, plant, diseases and pests. In: Marschner P (ed) Marschner's mineral nutrition of higher plants. Academic Press, Sydney, pp 2836-299. 
IRRI (2002). Standard evaluation system for rice. International Rice Research Institute, Los Banos, Manila, Philippines, p 14.

Jackson, M. L. (1967). Soil Chemical Analysis Prentice Hall of India Pvt. Ltd., New Delhi ; p. 205.

Kalboush, Z.A.A. (2007. Integrated management of brown spot disease of rice in Egypt. Ms. Thesis, Faculty of Agric., Kafr El-Sheikh Univ. Egypt.pp 98.

Katan, J. (2009). Mineral nutrient management and plant disease. In: research findings: e-ifc No. 21. International Potash Institute.

Khan, A.Z., H. Muhammad, S. K. Khalil, A. M. Ghoneim, S.Wahab, Z. Shah, H. Akbar, A. Muhammad (2016). Field evaluation of effective microorganisms (em) with organic and in-organic $n$ sources on growth, yield and nutrient concentration in wheat. Journal of Animal and Plant Sciences, 26(2):125-132.

Khanna, A. and M. M. Payak (1968).Teliospore morphology of some smut fungi. 11. Light microscopy. Mycologia 60 : 655-662.

Ladhalakshmi, D., G.S., Laha, R. Singh, A. Karthikeyan, S.K. Mangrauthia, R.M. Sundaram, P.Thukkaiyannan and B.C.Viraktamath (2012). Isolation and characterization of Ustilaginoidea virens and survey of false smut disease of rice in India. Phytoparasitica, 40: 171-176.

Mandhare, V.K., S.B.Gawade, B.C.Game and D.N. Padule (2008). Prevalence and incidence and false smut in paddy (Oryza sativa L.) seeds in Maharashtra. Agricultural Science Digest, 28: 292-4.

Manzali, D.; P. Nipoti, A. Pisi, G. Filippini and N.D. Ercole (1993). Scanning electron microscopy study of in vitro antagonism of Trichoderma sp., strains against R. S Kuhn. Mediterranean Phytopathpolgia, 32: 1-6.

Matsumoto, T.T., N.G. Whitney, M.R. Bonde and M.H. Royer (1985). Morphological variation of teliospores of N. horrida. Phytopathology, 75 : 1365.

Mundkur, B. B. (1939). A contribution towards a knowledge of Indian ustilaginales. Truns. Brit. Mycol. Soc. 23: 86-121.
Olsen, S.R., F.S. Cole, F.Watanabe and L.A. Dean (1954). Estimation of available phosphorus in soils by extraction with sodium bicarbonate, USDA, Circ.939.

Ou, S. H. (1985). Rice Diseases. CMI, Kew, p. 311-315.

Persson, J., P. Högberg, A. Ekblad, M.N. Högberg, A. Nordgren and T. Näsholm (2003). Nitrogen acquisition from inorganic and organic sources by boreal forest pants in the field. Oecologia, 137: 252-257.

Ramesh, P., M. Singh and A. Subba Rao (2005). Organic farming: Its relevance to the Indian context. Current Scientist, 88(4): 561-568.

Range, T. (1955). Multiple rang and multiple F. test. Biometrics. 11: 1-42.

Sharma,R.C., S. Neelu-Kohli and S.Gill (2001). Inoculation technique for kernel smut of paddy. Seed-Research, 29(2): 210-214.

Singh, R. S. (1990). Bunt of rice. In : Plant Diseases, VI ed. Oxford and IBH Publishing Co. Pvt. Ltd., New Delhi. p. 313-316.

Slaton, N. A.; E. E. J. Gbur; R. D. Cartwright; R. E. DeLong; R. J. Norman and K. R. Brye (2004). Grain yield and kernel smut of rice as affected by preflood and midseason nitrogen fertilization in Arkansas. Agronomy Journal, 96(1):91-99.

Slaton, N. A.; R. E. DeLong; R. J. Norman; R. D. Cartwright and C. E. J. Wilson (2007). Cultivar and seeding date effects on kernel smut of rice. Agronomy Journal, 99(2): 521-529.

Takahashi, Y. (1896). On Usti/ago virens Cooke and a new species of Tilletia parasitic on rice plant. Bot. Mag. Tokyo, 10: 16-20.

Trione, E. J. (1964). Isolation and in vitro culture of the wheat bunt fungi Tilletia caries and T. controversa Phytopathology, 54: 592-596.

Watanabe, F.S. and S.R.Olsen (1965). est of an ascorbic acid method for determining phosphorus in water and $\mathrm{NaHCO}_{3}$ extracts from soil. Soil Science Society of America Proceedings, 29, 677-678.

Zemolin, C.R. et al. (2009). Tilletia barclayana: Biologia e manejo em arroz irrigado. Ciência Rural., 39 (5): 1594-1599.

\section{تأثير الاسمدة المعنية والعضوية علي مرض التفحم الحبي في الأرز

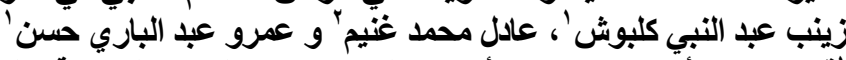

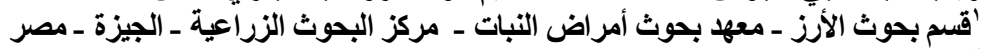

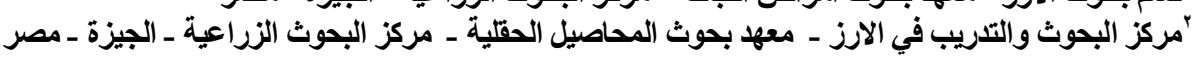

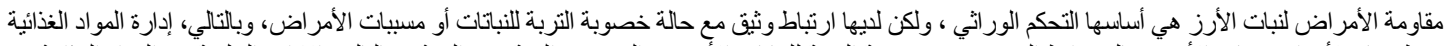

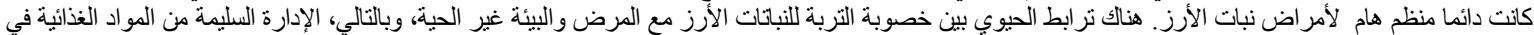

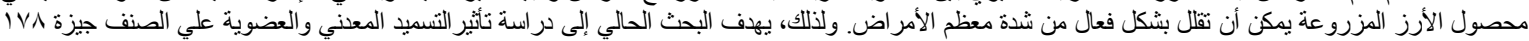

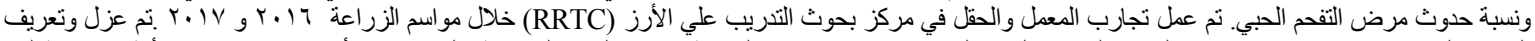

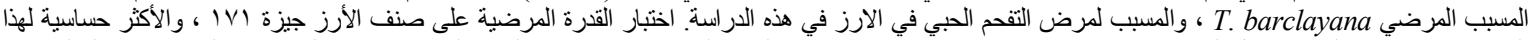

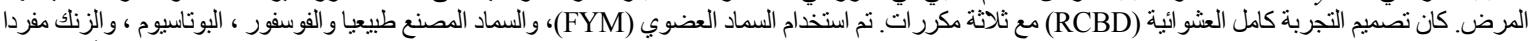

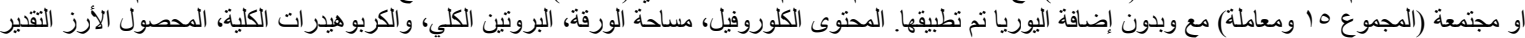

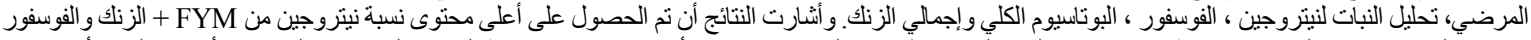

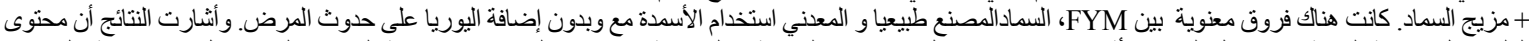

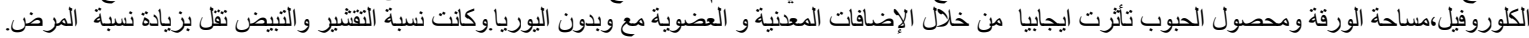

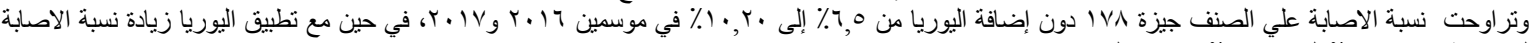

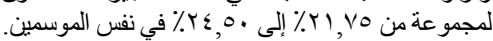

